\title{
Improving Joint Morphologies and Tensile Strength of Al/Mg Dissimilar Alloys Friction Stir Lap Welding by Changing Zn Interlayer Thickness
}

\author{
Jinglin Liu ${ }^{1}$ Shiyu Niu ${ }^{1} \cdot$ Rong Ren ${ }^{1} \cdot$ Shude $\mathrm{Ji}^{1} \cdot$ Lei Wang ${ }^{2} \cdot$ Zan Lv $^{1}$ \\ Received: 25 January 2019 / Revised: 1 April 2019 / Published online: 13 September 2019 \\ (C) The Chinese Society for Metals (CSM) and Springer-Verlag GmbH Germany, part of Springer Nature 2019
}

\begin{abstract}
The pure $\mathrm{Zn}$ foils with different thicknesses $(0.02,0.05,0.1,0.2$ and $0.3 \mathrm{~mm})$ were selected as interlayers to improve the quality of friction stir lap welding joint of 7075-T6 $\mathrm{Al}$ and $\mathrm{AZ31B} \mathrm{Mg}$ dissimilar alloys. The effects of the interlayer thickness on joint formation, microstructure and tensile strength were analyzed. The results displayed that the maximum length of the boundary between stir zone (SZ) and thermo-mechanically affected zone in lower plate was obtained by the addition of the $\mathrm{Zn}$ interlayer with $0.05 \mathrm{~mm}$ thickness. The $\mathrm{Mg}-\mathrm{Zn}$ intermetallic compounds (IMCs) were discontinuously distributed in the SZ, replacing the continuous Al-Mg IMCs. The size of Mg-Zn IMCs increased with the increase in the thickness of the $\mathrm{Zn}$ interlayer. The maximum tensile shear strength of $276 \mathrm{~N} \mathrm{~mm}^{-1}$ was obtained by the addition of $0.05 \mathrm{~mm} \mathrm{Zn}$ foil, which increased by $45.6 \%$ of that of the joint without the $\mathrm{Zn}$ foil addition.
\end{abstract}

Keywords $\mathrm{Al} / \mathrm{Mg}$ dissimilar alloys $\cdot$ Friction stir lap welding $\cdot \mathrm{Zn}$ foil thickness $\cdot$ Microstructure $\cdot$ Tensile shear strength

\section{Introduction}

Composite structures of $\mathrm{Al} / \mathrm{Mg}$ or $\mathrm{Al} / \mathrm{Cu}$ dissimilar materials can have advantages of two base materials (BMs), which have been widely used in aerospace and transportation fields $[1,2]$. The joining of $\mathrm{Al} / \mathrm{Mg}$ dissimilar alloys may be realized by different welding technologies such as laser welding [3], MIG welding [4] and other fusion welding technologies [5]. However, some defects such as crack, pore are easily formed and a large number of $\mathrm{Al}-\mathrm{Mg}$ intermetallic compounds (IMCs) such as $\mathrm{Al}_{12} \mathrm{Mg}_{17}$ and $\mathrm{Al}_{3} \mathrm{Mg}_{2}$ exist in the welding joint $[6,7]$. The hard and brittle $\mathrm{Al}-\mathrm{Mg}$ IMCs are

Jinglin Liu and Shiyu Niu have contributed equally to this work.

Available online at http://link.springer.com/journal/40195

Rong Ren

renrong@sau.edu.cn

Shude Ji

superjsd@163.com

1 College of Aerospace Engineering, Shenyang Aerospace University, Shenyang 110136, China

2 Shenyang Institute of Standardization, Shenyang 110021, China one of the most important factors which greatly affect the joint strength [5]. Therefore, how to reduce and even avoid the $\mathrm{Al}-\mathrm{Mg}$ IMCs in the welding joint has become a research hot spot.

Friction stir welding (FSW), a solid-state joining technology, is characterized by low thermal input and non-pollution $[8,9]$, which has been widely used to join similar or dissimilar materials $[10,11]$. Although the peak temperature during $\mathrm{FSW}$ for $\mathrm{Al} / \mathrm{Mg}$ dissimilar alloys is lower than melting points of BMs, the $\mathrm{Al}-\mathrm{Mg}$ IMCs are still unavoidable. Fu et al. [12] joined 6061-T6 Al alloy to AZ31B Mg alloy via FSW and found that the IMCs of $\mathrm{Al}_{12} \mathrm{Mg}_{17}$ and $\mathrm{Al}_{3} \mathrm{Mg}_{2}$ existed in the stir zone (SZ) at the butt joint. Ji et al. [13] reported that $6061 \mathrm{Al}$ and $\mathrm{AZ31Mg}$ alloys were successfully joined via friction stir lap welding (FSLW), and the results displayed that $\mathrm{Al}_{12} \mathrm{Mg}_{17}$ and $\mathrm{Al}_{3} \mathrm{Mg}_{2}$ were the main IMCs formed in the SZ at the lap joint. The hard and brittle Al-Mg IMCs control the failure mode of the lap joint and significantly reduce the joint strength [14].

In order to obtain a high-strength FSLW joint of $\mathrm{Al} / \mathrm{Mg}$ dissimilar alloys, some researchers have employed a kind of $\mathrm{Zn}$ foil as an interlayer. Gan and Jin [15] selected the pure $\mathrm{Zn}$ foil acting as a barrier layer and carried out the friction stir-induced diffusion bonding of 6061-T6 Al and AZ31B $\mathrm{Mg}$ dissimilar alloys. The results stated that the $\mathrm{Zn}$ interlayer 
impeded the reaction between upper $\mathrm{Al}$ and lower $\mathrm{Mg}$, and no Al-Mg IMCs were formed in the joint. However, it is difficult to ensure the distance between the $\mathrm{Zn}$ interlayer and the pin tip of rotating tool in the practical engineering production, so the performance consistency of the lap joint cannot be ensured by friction stir-induced diffusion bonding. This problem can be solved by plunging the rotating pin into the lower plate during FSLW. Niu et al. [16] found that when the rotating pin plunged into the lower plate, the tensile shear strength of dissimilar AZ31B Mg/7075-T6 Al alloys FSLW joint could be greatly improved by the addition of the $\mathrm{Zn}$ interlayer, which was because that the $\mathrm{Al}-\mathrm{Mg}$ IMCs in the $\mathrm{SZ}$ were replaced by the $\mathrm{Mg}-\mathrm{Zn}$ IMCs.

As mentioned above, $\mathrm{Al}-\mathrm{Mg}$ IMCs can be replaced by the $\mathrm{Mg}-\mathrm{Zn}$ IMCs when the $\mathrm{Zn}$ foil is selected as an interlayer [17]. Moreover, the amount of $\mathrm{Zn}$ in the SZ is a key factor significantly influencing the joint strength. Farahani and Divandari [18] joined the pure $\mathrm{Al}$ and $\mathrm{Mg}$ via FSLW by the $\mathrm{Zn}$ interlayers with the thicknesses of $100 \mu \mathrm{m}, 200 \mu \mathrm{m}$ and $400 \mu \mathrm{m}$, respectively. The results stated that the maximum joint strength of $76 \mathrm{~N} \mathrm{~mm}^{-2}$ was obtained when the thickness of $\mathrm{Zn}$ interlayer was $100 \mu \mathrm{m}$. At present, there are few researches on FSLW of $\mathrm{Al} / \mathrm{Mg}$ dissimilar alloys with a $\mathrm{Zn}$ interlayer by plunging the rotating pin into the lower plate, and the selection of the $\mathrm{Zn}$ interlayer thickness is unilateral [16-18]. On the basis of previous works [16, 17], the effects of the $\mathrm{Zn}$ interlayer thickness on the joint formation, microstructure and tensile property of FSLW joint were studied systematically in this study.

\section{Experimental Procedure}

AZ31B Mg and 7075-T6 Al alloys were selected as the BMs. The compositions of BMs are presented in Table 1. The dimensions of the welded plates were $180 \mathrm{~mm} \times 150 \mathrm{~mm} \times 3 \mathrm{~mm}$. Pure $\mathrm{Zn}$ foils were used as the interlayers. The $\mathrm{Zn}$ foils were cut into a dimension of $180 \mathrm{~mm} \times 50 \mathrm{~mm}$. The thicknesses of the $\mathrm{Zn}$ foils used in this study were $0.02 \mathrm{~mm}, 0.05 \mathrm{~mm}, 0.1 \mathrm{~mm}, 0.2 \mathrm{~mm}$ and $0.3 \mathrm{~mm}$, respectively. Before welding, the BMs were polished by sand paper to remove the oxide layer, and then cleaned by alcohol. Mg alloy was placed as the upper plate according to the previous works [16, 17]. Figure 1 displays the schematic of the $\mathrm{Zn}$-added FSLW process of Al/Mg dissimilar alloys. The rotating tool was made of $\mathrm{H} 13$ steel, and the diameter of shoulder and the length of the rotating pin

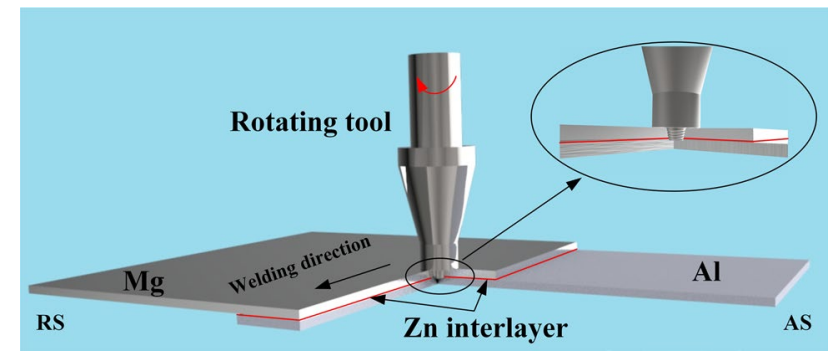

Fig. 1 Schematic of the Zn-added FSLW process

were $14 \mathrm{~mm}$ and $3.65 \mathrm{~mm}$, respectively. The tilt angle of the tool was $2.5^{\circ}$ with respect to $Z$ axis, and the plunge depth of the shoulder was $0.15 \mathrm{~mm}$. The welding parameters significantly influence the joint strength. According to the report by Niu et al. [16], the rotating velocity of $1000 \mathrm{rpm}$ and the welding speed of $50 \mathrm{~mm} / \mathrm{min}$ were selected.

The specimens for metallograph and tensile shear were cut by an electrical discharge cutting machine. After polishing in accordance with the standard of metallography, the $\mathrm{Mg}$ side of the specimen was etched by a solution of $5 \mathrm{ml}$ acetic acid, $4.2 \mathrm{~g}$ picric acid, $10 \mathrm{ml}$ distilled water and $100 \mathrm{ml}$ ethanol for $12 \mathrm{~s}$. The microstructures were analyzed by the optical microscope (OM OLYMPUS, GX71) and the scanning electron microscope (SEM, SU3500) equipped with an energy-dispersive X-ray spectrometer (EDS). The phases at the joints under different welding processes were examined by X-ray powder diffractometer (XRD Rigaku Ultima IV) with the analysis angles from $20^{\circ}$ to $100^{\circ}$. The width of the tensile shear specimen was $30 \mathrm{~mm}$. Three specimens were prepared for each welding process, and an average value was used to analyze. The fracture path was observed using a stereomicroscope, and the fracture surface was revealed by the SEM and the XRD.

\section{Results and Discussion}

\subsection{Joint Formation}

Figure 2 displays the cross-sectional morphologies of the joints under different welding processes. The sound joints without defects are attained under the conventional and the $0.02,0.05,0.1$ and $0.2 \mathrm{~mm} \mathrm{Zn}$-added FSLW processes (Fig. 2a-e). Some cavities exist in the $\mathrm{SZ}$ at $0.3 \mathrm{~mm} \mathrm{Zn-}$ added joint (Fig. 2f). For the conventional joint, although
Table 1 Chemical compositions of 7075-T6 $\mathrm{Al}$ and $\mathrm{AZ31B} \mathrm{Mg}$ alloys (mass\%)

\begin{tabular}{llllllllll}
\hline Material & $\mathrm{Cu}$ & $\mathrm{Fe}$ & $\mathrm{Si}$ & $\mathrm{Mg}$ & $\mathrm{Mn}$ & $\mathrm{Zn}$ & $\mathrm{Cr}$ & $\mathrm{Ni}$ & $\mathrm{Al}$ \\
\hline 7075-T6 & 1.64 & 0.24 & 0.42 & 2.49 & 0.3 & 5.72 & 0.21 & - & $\mathrm{Bal}$. \\
AZ31B & 0.0015 & 0.0027 & 0.12 & $\mathrm{Bal}$. & 0.48 & 0.88 & - & 0.0005 & 3.1 \\
\hline
\end{tabular}



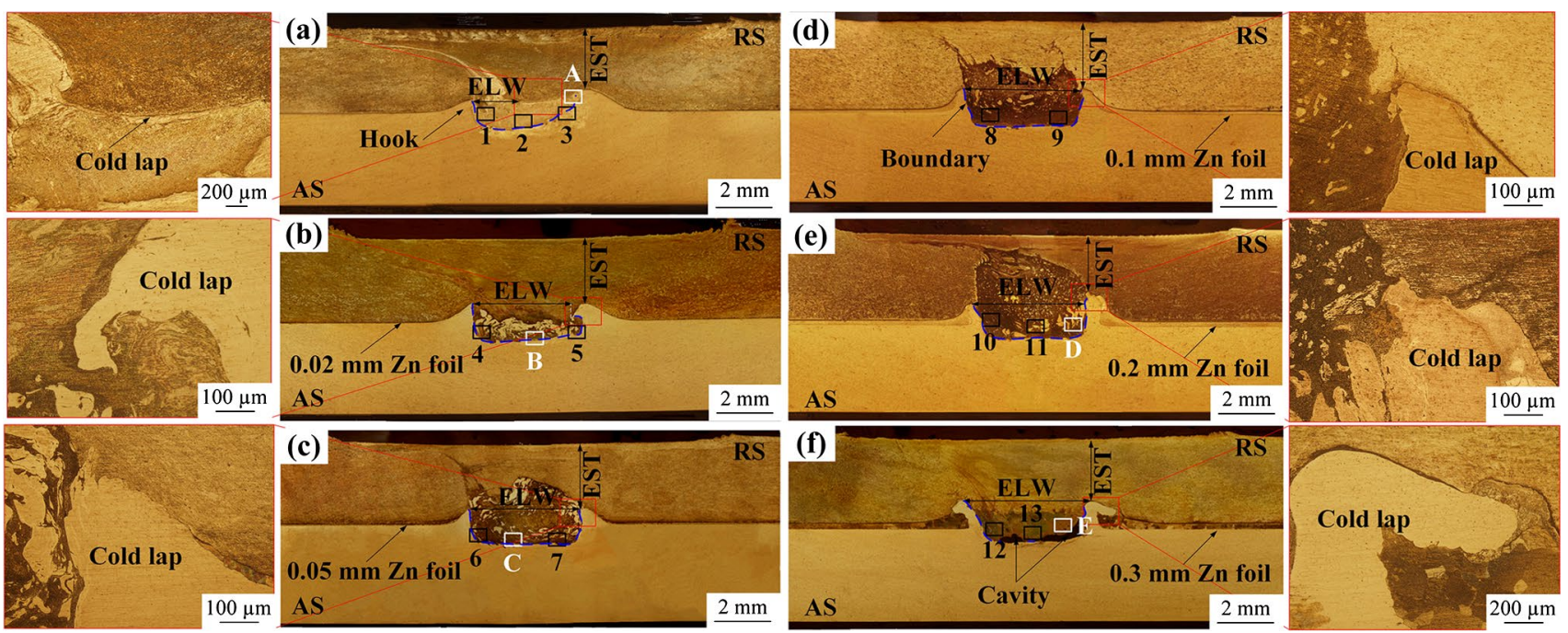

Fig. 2 Cross sections of the joints: a the conventional joint, b $0.02 \mathrm{~mm}, \mathbf{c} 0.05 \mathrm{~mm}, \mathbf{d} 0.1 \mathrm{~mm}, \mathbf{e} 0.2 \mathrm{~mm}, \mathbf{f} 0.3 \mathrm{~mm} \mathrm{Zn}$-added joints

mechanical interlocking is formed in the SZ, the effective lap width (ELW) and the size of SZ bottom are smaller than those of the $\mathrm{Zn}$-added joints. The ELW means a horizontal distance between the tip of hook at advancing side (AS) and the tip of cold lap at retreating side (RS), which is one of the significant factors affecting the tensile property of the FSLW joint [19]. The difference in the formation between the conventional and $\mathrm{Zn}$-added joints is related to the flow behavior of materials. The materials in the SZ top are transferred downward by rotating pin with right-hand thread which rotates counterclockwise during FSLW. The transferred materials are released at the pin tip, producing a pushing force on the materials in the thermo-mechanically affected zone (TMAZ) [20]. Therefore, the materials in the TMAZ are transferred upward, forming the hook and the cold lap at the AS and the RS, respectively (Fig. 2a). The cold lap at the RS extends into the $\mathrm{SZ}$ at the conventional joint due to the combination effects between the rotating pin and the shoulder, forming a small ELW. Yue et al. [21] obtained a similar result of the small ELW in the FSLW joint of $2024 \mathrm{Al}$ alloy. For the $\mathrm{Zn}$-added joints, the cross-sectional morphologies are greatly changed by the $\mathrm{Zn}$ foil addition (Fig. 2b-f). The melting point of $\mathrm{Zn}$ is $419.5^{\circ} \mathrm{C}$ which is lower than the peak temperature during FSLW [22]. The molten $\mathrm{Zn}$ in the SZ is stirred and transferred by the rotating pin and eventually dispersed in the SZ bottom. The dispersed $\mathrm{Zn}$ as a lubricant is beneficial to reducing the friction coefficient between the materials, and then decreasing the flow stress of the materials in the SZ bottom [16]. Therefore, the SZ bottom is enlarged, and part of the cold lap extending into the $\mathrm{SZ}$ is broken and then dispersed in the SZ bottom, thereby increasing the ELW of the joint.
It is noteworthy that the $0.3 \mathrm{~mm} \mathrm{Zn}$-added joint presents a different morphology compared with other $\mathrm{Zn}$-added joints. The hook and cold lap are bent toward the TMAZ instead of the SZ, and no Al substrate exists in the SZ (Fig. 2f). During the plunge stage of FSLW, a large number of molten $\mathrm{Zn}$ is extruded from the $\mathrm{SZ}$ and then accumulated at the lap interface in the TMAZ [23]. The upward transferred materials in the TMAZ are easily bent toward the molten $\mathrm{Zn}$ side according to the law of minimum resistance, thereby resulting in the morphologies of the hook and the cold lap in the $0.3 \mathrm{~mm} \mathrm{Zn-added} \mathrm{joint.} \mathrm{Moreover,} \mathrm{the} \mathrm{materials} \mathrm{in}$ the SZ are not sufficient to fill the cavity left behind the rotating pin because no $\mathrm{Al}$ substrate is transferred into the SZ, forming the cavity defect (Fig. 2f). The cavity defect also existed at the SZ bottom of the $400 \mu \mathrm{m} \mathrm{Zn-added} \mathrm{joint}$ in the study of Farahani and Divandari [18]. Although the reason of defect formation has not been explained in Ref. [18], it can be concluded that excessive $\mathrm{Zn}$ is responsible for the defect formation.

Figure 3 exhibits the ELWs and the boundary lengths between the SZ bottom and the TMAZ in lower plate under different processes (Fig. 2a). The ELW is obviously increased when the $\mathrm{Zn}$ foil is used as the interlayer, and its value is mainly increased with increasing the $\mathrm{Zn}$ foil thickness. This is because that the flow rate of the materials in the SZ bottom is faster when the amount of $\mathrm{Zn}$ is increased. Besides the ELW, the boundary length is another significant factor affecting the tensile property of the FSLW joint. Compared with the conventional joint, the boundary length is also significantly increased by the $\mathrm{Zn}$ foil addition. For the 0.1 and $0.2 \mathrm{~mm} \mathrm{Zn-added} \mathrm{joints,} \mathrm{the} \mathrm{materials} \mathrm{in} \mathrm{the} \mathrm{SZ}$ bottom are more closed to the liquid state due to the large amount of molten $\mathrm{Zn}$. The pushing force, which is produced 


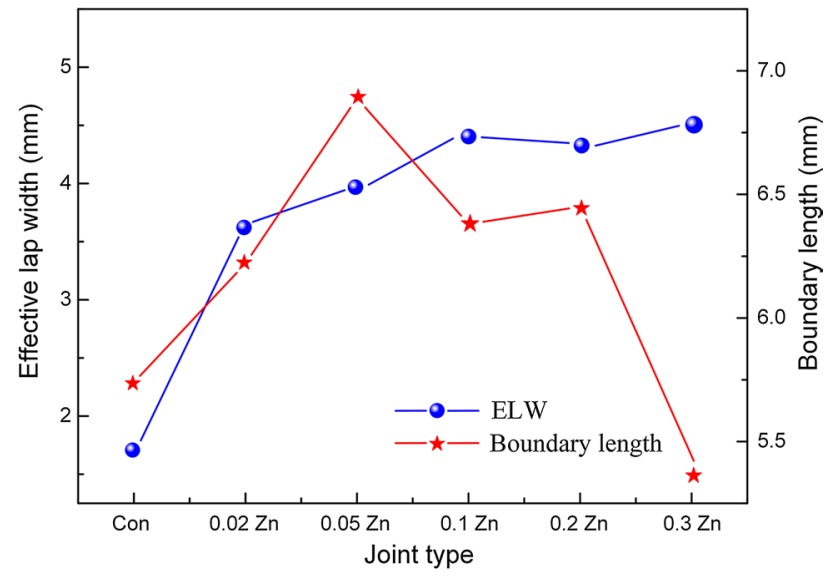

Fig. 3 ELWs and the boundary lengths between SZ and TMAZ in lower plate under different processes by the materials accumulated at the pin tip in the SZ bottom, on the materials in the TMAZs at the 0.1 and $0.2 \mathrm{~mm}$ joints is smaller compared with that at the $0.05 \mathrm{~mm}$ joint. Moreover, the boundary length of the $0.3 \mathrm{~mm}$ joint is the smallest due to the large cavities existing along the boundary. The maximum boundary length of $6.89 \mathrm{~mm}$ is attained when the thickness of the $\mathrm{Zn}$ interlayer is $0.05 \mathrm{~mm}$.

\subsection{Microstructure}

The microstructure also significantly affects the joint quality [24]. For further investigate, the effects of $\mathrm{Zn}$ foil thickness on the tensile property of the joint, the microstructure is analyzed based on the SEM, EDS and XRD results in Figs. 4, $5,6,7,8$ and 9 .

Figure 4 presents enlarged views of regions marked in the conventional joint (Fig. 2a). The structures mainly have two representative morphologies: cluster shape (Fig. 4a) and lamellar shape (Fig. 4b, c). The EDS results in Table 2 display that the black substrate in point 1 marked in Fig. 2a
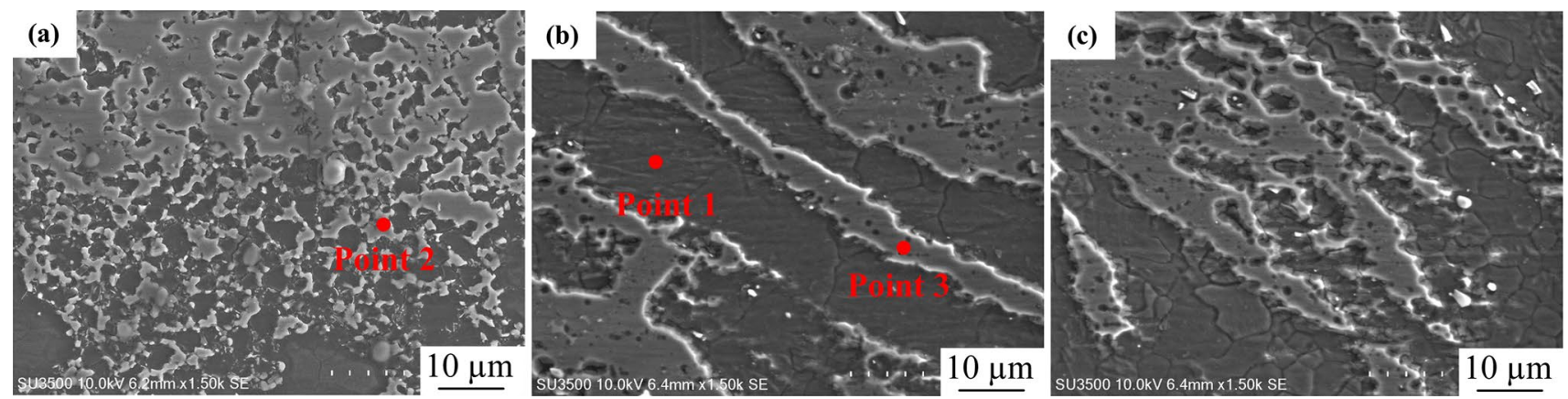

Fig. 4 SEM images of the regions at the conventional joint marked in Fig. 2a: a region 1, b region 2, c region 3
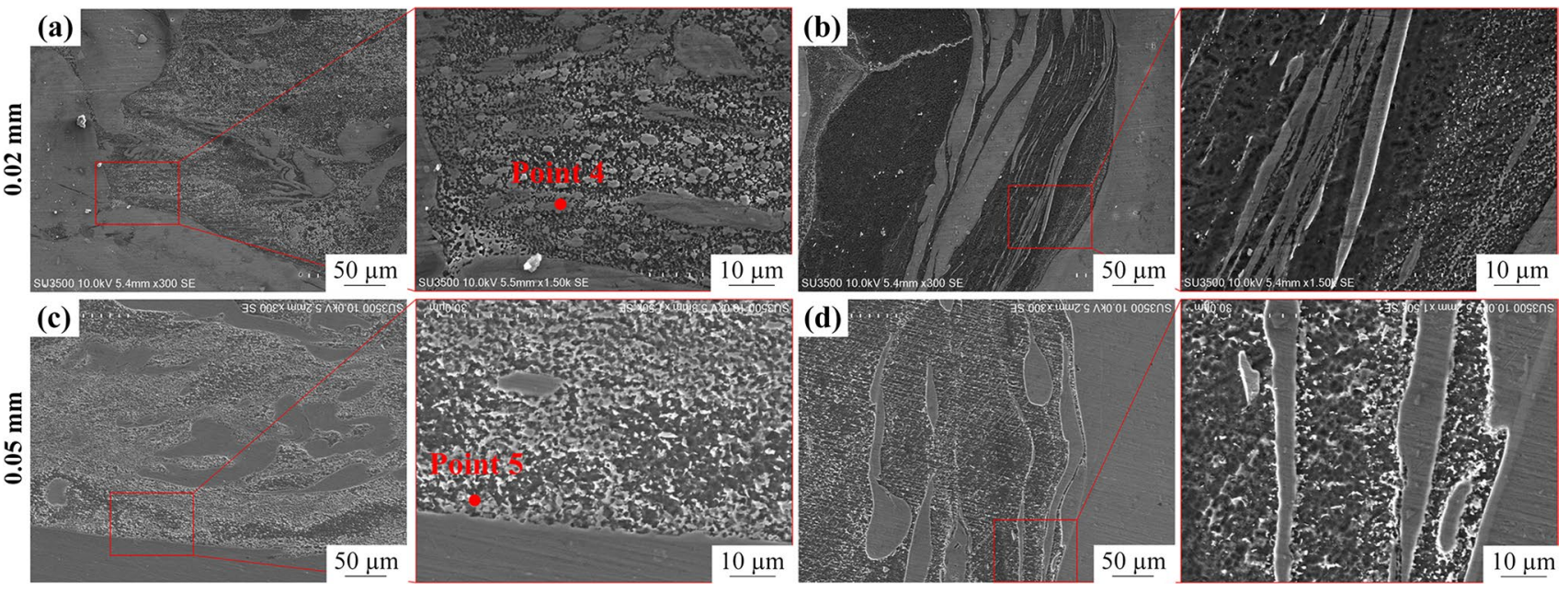

Fig. 5 SEM images of the regions at the 0.02 and $0.05 \mathrm{~mm} \mathrm{Zn-added} \mathrm{joints:} \mathrm{a,} \mathrm{b} \mathrm{regions} 4$ and 5 marked in Fig. 2 b, c, d regions 6 and 7 marked in Fig. 2c 


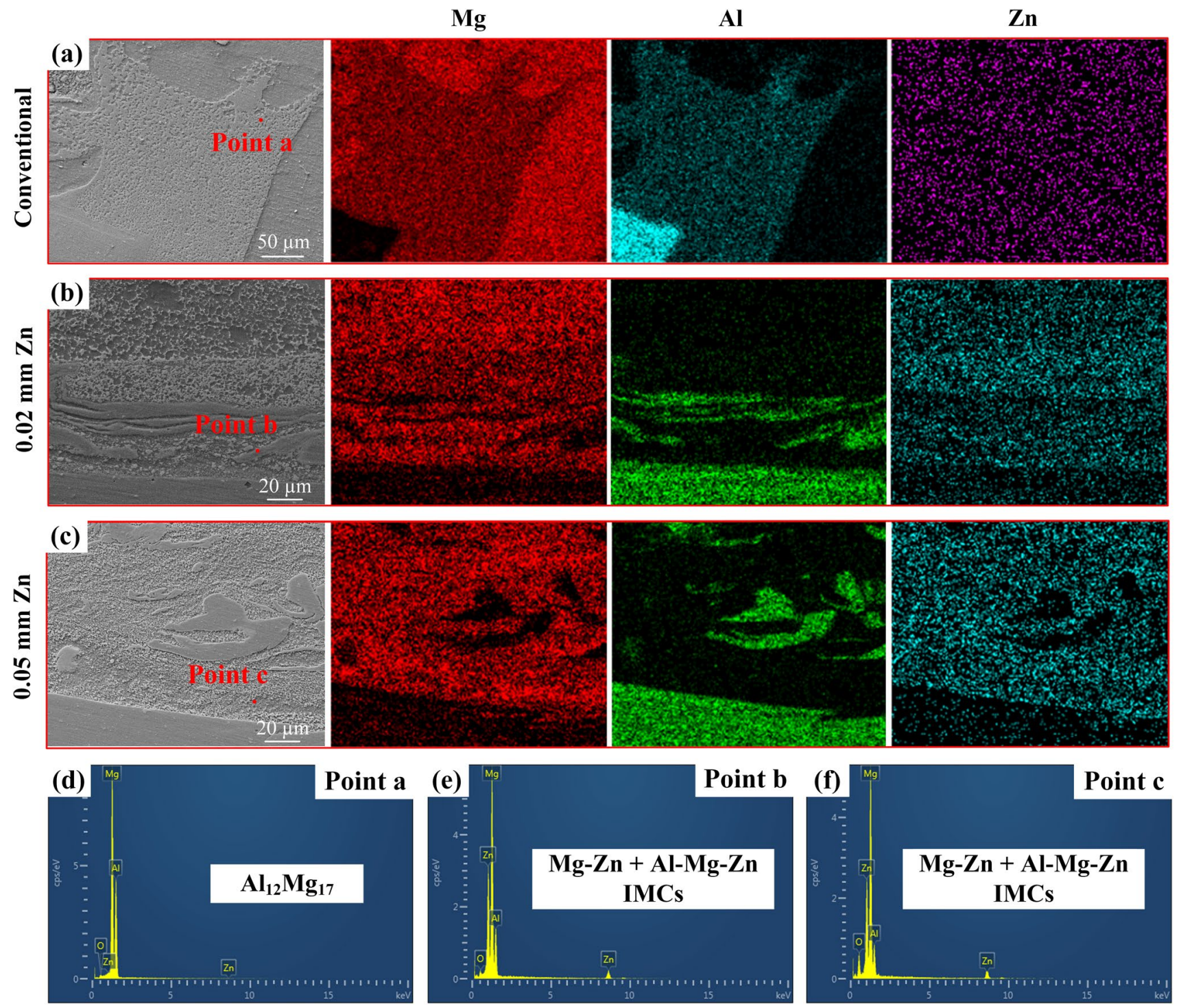

Fig. 6 EDS results: a-c regions A-C marked in Fig. 2, $\mathbf{d}-\mathbf{f}$ points a-c marked in a-c

is $\mathrm{Mg}$ substrate. The cluster structure in point 2 consists of 55.3 at. $\% \mathrm{Mg}$ and 42.1 at.\% $\mathrm{Al}$, and the lamellar structure in point 3 is composed of 37.2 at. $\% \mathrm{Mg}$ and 60.3 at.\% $\mathrm{Al}$, as shown in Table 2. According to the Al-Mg binary phase diagram, two eutectic reactions occur during the solidification process. One is $\mathrm{L} \rightarrow \mathrm{Al}_{12} \mathrm{Mg}_{17}+\mathrm{Mg}$ at the eutectic temperature of $437{ }^{\circ} \mathrm{C}$, the other is $\mathrm{L} \rightarrow \mathrm{Al}_{3} \mathrm{Mg}_{2}+\mathrm{Al}$ at the eutectic temperature of $450{ }^{\circ} \mathrm{C}$ [25]. The eutectic temperatures between $\mathrm{Al}$ and $\mathrm{Mg}$ are lower than the peak temperature during FSW [7]. Therefore, the cluster and lamellar structures are, respectively, $\mathrm{Al}_{12} \mathrm{Mg}_{17}$ and $\mathrm{Al}_{3} \mathrm{Mg}_{2}$, which are the hard and brittle IMCs [16]. Figure 6a shows that the $\mathrm{Al}-\mathrm{Mg}$ IMCs are concentrated at the boundary between the $\mathrm{Al}$ and $\mathrm{Mg}$ substrates. The XRD results in Fig. 9a confirm the above analyses of EDS results that the IMCs in the $\mathrm{SZ}$ at the conventional joint are mainly $\mathrm{Al}_{12} \mathrm{Mg}_{17}$ and
$\mathrm{Al}_{3} \mathrm{Mg}_{2}$. Abdollahzadeh et al. [26] reported similar IMCs in the FSLW joint of $\mathrm{Al} / \mathrm{Mg}$ dissimilar alloys, and they stated that these brittle and hard Al-Mg IMCs were harmful to the joint strength.

The microstructures in the SZs at the Zn-added joints present many differences compared to the convention joint as shown in Figs. 5 and 7. The EDS results in Tables 2 and 3 illustrate that the IMCs in the SZs at the Zn-added joints are mainly $\mathrm{Mg}-\mathrm{Zn}$ and $\mathrm{Al}-\mathrm{Mg}-\mathrm{Zn}$. The XRD results (Fig. 9b) reveal that these IMCs are mainly $\mathrm{Al}_{5} \mathrm{Mg}_{11} \mathrm{Zn}_{4}$, $\mathrm{AlMg}_{4} \mathrm{Zn}_{11}, \mathrm{Mg}_{7} \mathrm{Zn}_{3}$ and $\mathrm{MgZn}_{2}$. Gan and Jin [15] also reported the similar IMCs existence in the dissimilar Al/ $\mathrm{Mg}$ alloys friction stir-induced diffusion bonding joint with a $\mathrm{Zn}$ interlayer. The $\mathrm{SZ}$ at the $\mathrm{Zn}$-added joint in this study is a mixture of $\mathrm{Al} / \mathrm{Mg} / \mathrm{Zn}$. According to $\mathrm{Al}-\mathrm{Mg}-\mathrm{Zn}$ phase diagram, $\mathrm{L} \rightarrow \mathrm{Mg}-\mathrm{Zn}$ and $\mathrm{L} \rightarrow \mathrm{Mg}-\mathrm{Zn}+\mathrm{Al}-\mathrm{Mg}-\mathrm{Zn}$ occur 

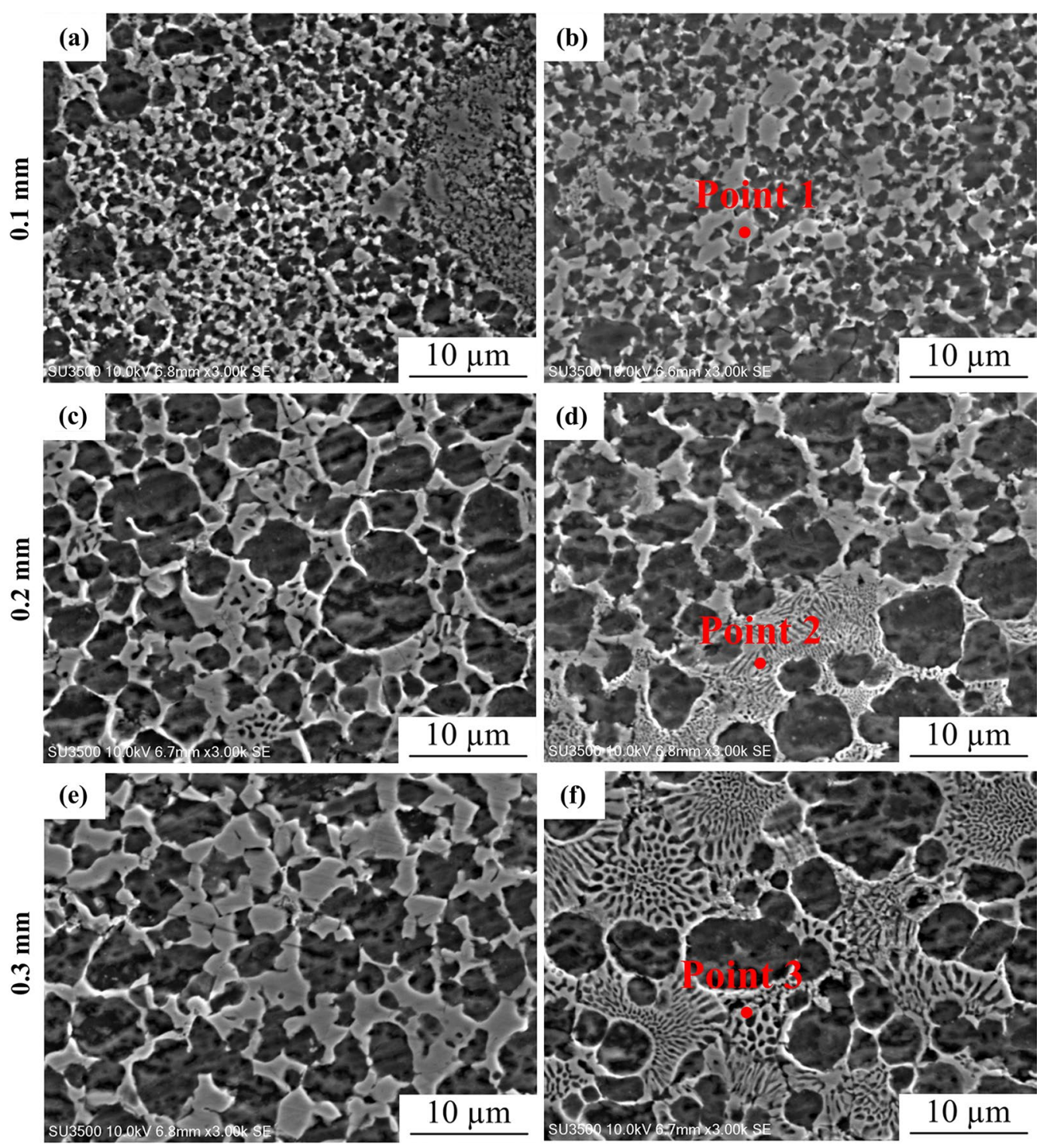

Fig. 7 Enlarged views of the regions at the $0.1,0.2$ and $0.3 \mathrm{~mm} \mathrm{Zn-added} \mathrm{joints:} \mathrm{a,} \mathrm{b} \mathrm{regions} 8$ and 9 marked in Fig. $2 \mathrm{~d}, \mathbf{c}, \mathbf{d}$ regions 10 and 11 marked in Fig. 2e, e, f regions 12 and 13 marked in Fig. $2 \mathrm{f}$

at the eutectic temperatures of $480{ }^{\circ} \mathrm{C}$ and $340{ }^{\circ} \mathrm{C}$, respectively, during the solidification process [27]. Moreover, $\mathrm{Zn}$ and $\mathrm{Mg}$ have the same crystal lattice [28]. Therefore, the $\mathrm{Mg}-\mathrm{Zn}$ and $\mathrm{Al}-\mathrm{Mg}-\mathrm{Zn}$ IMCs are preferentially formed before the Al-Mg IMCs. Compared with Al-Mg IMCs in the conventional joint, the fine $\mathrm{Mg}-\mathrm{Zn}$ and $\mathrm{Al}-\mathrm{Mg}-\mathrm{Zn}$ IMCs are uniformly and discontinuously distributed in the SZs at the $0.02,0.05$ and $0.1 \mathrm{~mm} \mathrm{Zn-added} \mathrm{joints.} \mathrm{During} \mathrm{the} \mathrm{Zn}$ added FSLW, the molten $\mathrm{Zn}$ is transferred vertically and horizontally with the rotation of the rotating tool, and finally dispersed in the SZ, as shown in Fig. 6b, c. The nucleation sites of the $\mathrm{Mg}-\mathrm{Zn}$ and $\mathrm{Al}-\mathrm{Mg}-\mathrm{Zn}$ IMCs are more and better distributed compared to the Al-Mg IMCs in the conventional joint when the eutectic reactions occur. For the $0.02,0.05$ and $0.1 \mathrm{~mm}$ joints, it is difficult for $\mathrm{Mg}-\mathrm{Zn}$ and
Al-Mg-Zn IMCs to grow into a continuous morphology because of the fast cooling rate and the small amount of $\mathrm{Zn}$.

Besides the fine particles, some block structures exist in the SZ bottom at the $0.02 \mathrm{~mm}$ joint (Fig. 5a). The EDS results in point 4 show that the structures are mainly $\mathrm{Al}-\mathrm{Mg}-\mathrm{Zn}$ and a small number of $\mathrm{Al}_{12} \mathrm{Mg}_{17}$ (Table 2). Therefore, the $\mathrm{Zn}$ interlayer with $0.02 \mathrm{~mm}$ thickness cannot provide sufficient $\mathrm{Zn}$ to form $\mathrm{Mg}-\mathrm{Zn}$ and $\mathrm{Al}-\mathrm{Mg}-\mathrm{Zn}$ IMCs which completely replace the Al-Mg IMCs. For the $0.05 \mathrm{~mm}$ joint, the $\mathrm{Mg}-\mathrm{Zn}$ and $\mathrm{Al}-\mathrm{Mg}-\mathrm{Zn}$ IMCs particles (point 5) are formed and discontinuously distributed at the boundaries between the SZ bottom and the TMAZ in the lower plate (Fig. 5c, d), and the block structure containing $\mathrm{Al}_{12} \mathrm{Mg}_{17}$ at the $0.02 \mathrm{~mm}$ joint disappears. The EDS results of the regions at the 0.02 and $0.05 \mathrm{~mm}$ joints are shown in 


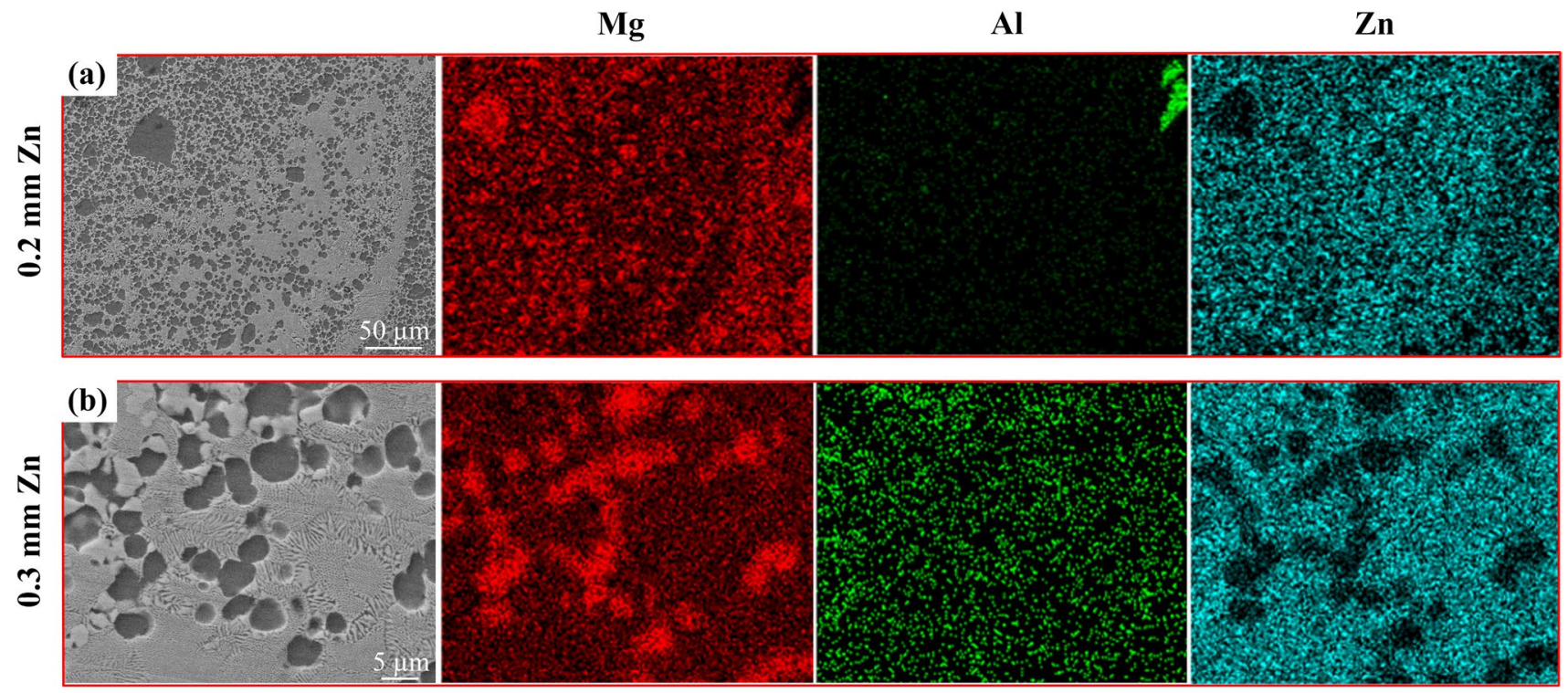

Fig. 8 EDS results of the regions marked in Fig. 2: $\mathbf{a}, \mathbf{b}$ regions D and E
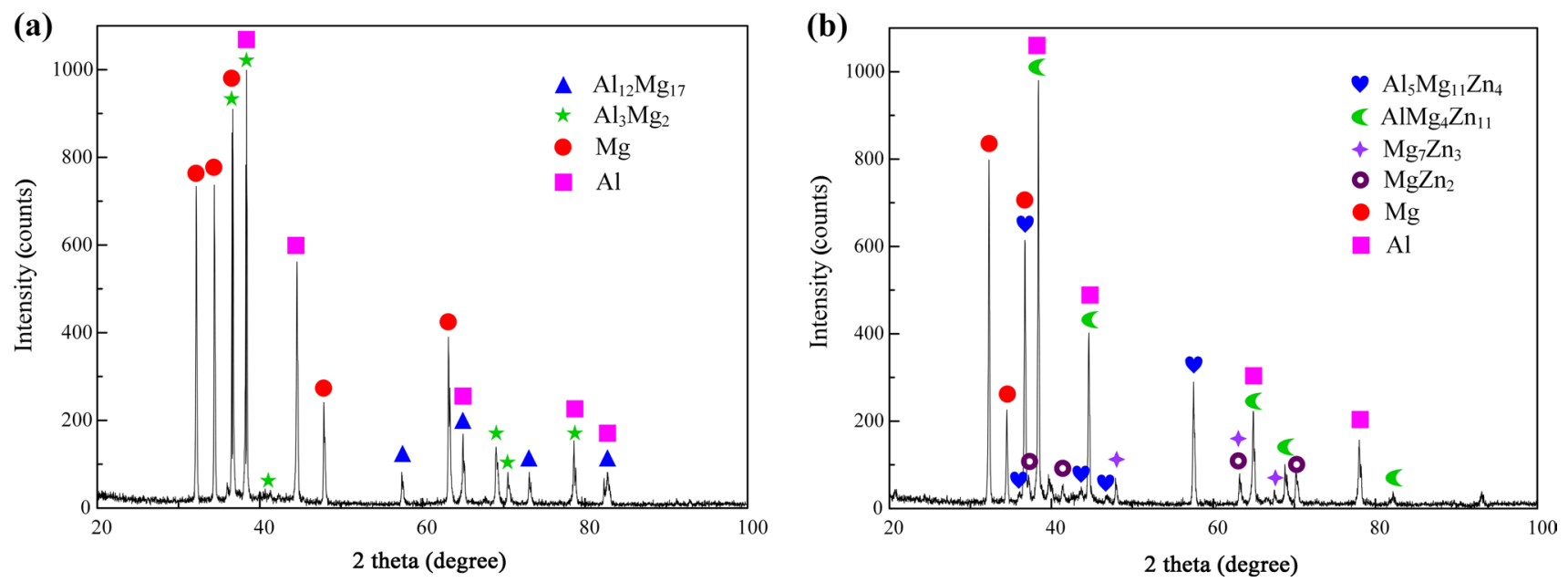

Fig. 9 XRD patterns on the cross sections: a the conventional joint, $\mathbf{b}$ the $0.05 \mathrm{~mm} \mathrm{Zn}$-added joint

Table 2 EDS results of points 1-5 marked in Fig. 2

\begin{tabular}{llrrll}
\hline Point & \multicolumn{3}{l}{ Composition (at.\%) } & \multicolumn{2}{l}{ Possible phase } \\
\cline { 2 - 4 } & $\mathrm{Mg}$ & \multicolumn{1}{c}{$\mathrm{Al}$} & \multicolumn{1}{c}{$\mathrm{Zn}$} & $\mathrm{O}$ & \\
\hline 1 & 93.3 & 3.2 & 0.9 & 2.6 & $\mathrm{Mg}$ substrate \\
2 & 55.3 & 42.1 & 0.8 & 1.8 & $\mathrm{Al}_{12} \mathrm{Mg}_{17}$ \\
3 & 37.2 & 60.3 & 0.8 & 1.7 & $\mathrm{Al}_{3} \mathrm{Mg}_{2}$ \\
4 & 50.5 & 40.1 & 7.7 & 1.7 & $\mathrm{Al}-\mathrm{Mg}-\mathrm{Zn}+\mathrm{Al}_{12} \mathrm{Mg}_{17}$ \\
5 & 47.1 & 24.9 & 25.7 & 2.3 & $\mathrm{Mg}-\mathrm{Zn}+\mathrm{Al}-\mathrm{Mg}-\mathrm{Zn}$ \\
\hline
\end{tabular}

Fig. 6b, c. It can be known that the main elements in the $\mathrm{SZ}$ are $\mathrm{Mg}$ and $\mathrm{Zn}$, and the $\mathrm{Mg}-\mathrm{Zn}$ and $\mathrm{Al}-\mathrm{Mg}-\mathrm{Zn}$ IMCs are uniformly distributed in the SZ (Fig. 6e, f). Compared
Table 3 EDS results of points 1-3 marked in Fig. 7

\begin{tabular}{llrlll}
\hline Point & \multicolumn{3}{l}{ Composition (at.\%) } & Possible phase \\
\cline { 2 - 4 } & $\mathrm{Mg}$ & \multicolumn{1}{c}{$\mathrm{Al}$} & $\mathrm{Zn}$ & $\mathrm{O}$ & \\
\hline 1 & 47.3 & 19.6 & 30.6 & 2.5 & $\mathrm{Mg}-\mathrm{Zn}+\mathrm{Al}-\mathrm{Mg}-\mathrm{Zn}$ \\
2 & 60.1 & 9.7 & 28.2 & 2.0 & $\mathrm{Mg}-\mathrm{Zn}$ \\
3 & 53.9 & 6.4 & 34.4 & 2.3 & $\mathrm{Mg}-\mathrm{Zn}$ \\
\hline
\end{tabular}

with the $100 \mu \mathrm{m} \mathrm{Zn-added} \mathrm{joint} \mathrm{in} \mathrm{the} \mathrm{study} \mathrm{of} \mathrm{Farahani}$ and Divandari [18] which has the best quality, the sizes of IMCs particles at the 0.02 and $0.05 \mathrm{~mm}$ joints in this study are significantly smaller. 
Figure 7 displays the microstructures in the SZs at the 0.1, 0.2 and $0.3 \mathrm{~mm} \mathrm{Zn-added} \mathrm{joints.} \mathrm{The} \mathrm{EDS} \mathrm{results} \mathrm{of} \mathrm{points}$ 1-3 marked in Fig. 7 show that the IMCs at the 0.1, 0.2 and $0.3 \mathrm{~mm}$ joints are mainly $\mathrm{Mg}-\mathrm{Zn}$ IMCs (Table 3 ). Although no $\mathrm{Al}-\mathrm{Mg}$ IMCs can be observed, the size of the $\mathrm{Mg}-\mathrm{Zn}$ IMCs is much larger than that of the 0.02 and $0.05 \mathrm{~mm}$ joints. It is noteworthy that the $\mathrm{Mg}-\mathrm{Zn}$ IMCs with a small size at the $0.1 \mathrm{~mm}$ joint are still discontinuous (Fig. 7a, b). However, the $\mathrm{Mg}-\mathrm{Zn}$ IMCs with a large size are continuously distributed at the 0.2 and $0.3 \mathrm{~mm}$ joints (Fig. 7c-f). This result shows that the amounts of $\mathrm{Zn}$ in the SZs at the 0.2 and $0.3 \mathrm{~mm} \mathrm{Zn}$-added joints are high, leading to an excessive growth of $\mathrm{Mg}-\mathrm{Zn}$ IMCs and eventually presenting a continuous morphology. Moreover, some continuous cobweb structures exist in the SZs at the 0.2 and $0.3 \mathrm{~mm}$ joints, and the size and amount of these structures at $0.3 \mathrm{~mm}$ joint are larger than those at the $0.2 \mathrm{~mm}$ joint (Fig. 7d, f). According to EDS results of the regions at 0.2 and $0.3 \mathrm{~mm}$ joints, $\mathrm{Zn}$ is the main constituent of these continuous cobweb structures (Fig. 8). The existence of the cobweb structures can confirm the above conclusion that the amounts of $\mathrm{Zn}$ in the SZs at the 0.2 and $0.3 \mathrm{~mm}$ joints are excess.

\subsection{Tensile Property}

Figure 10 presents the tensile shear strength of the joints under different processes. A ratio $\left(\mathrm{N} \mathrm{mm}^{-1}\right)$ of maximum tensile shear load to the width of the tensile specimen is used as a standard to quantify tensile shear strength [29]. The tensile shear strength of the conventional joint is $190 \mathrm{~N} \mathrm{~mm}^{-1}$, while those at $0.02,0.05,0.1$ and $0.2 \mathrm{~mm} \mathrm{Zn-added} \mathrm{joints}$ are, respectively, 244, 276, 220 and $209 \mathrm{~N} \mathrm{~mm}^{-1}$, increasing by $54,86,30$ and $19 \mathrm{~N} \mathrm{~mm}^{-1}$ compared to the conventional joint. However, the strength at $0.3 \mathrm{~mm}$ joint is smaller than that of the conventional joint. The differences of the tensile properties between the joints under different processes

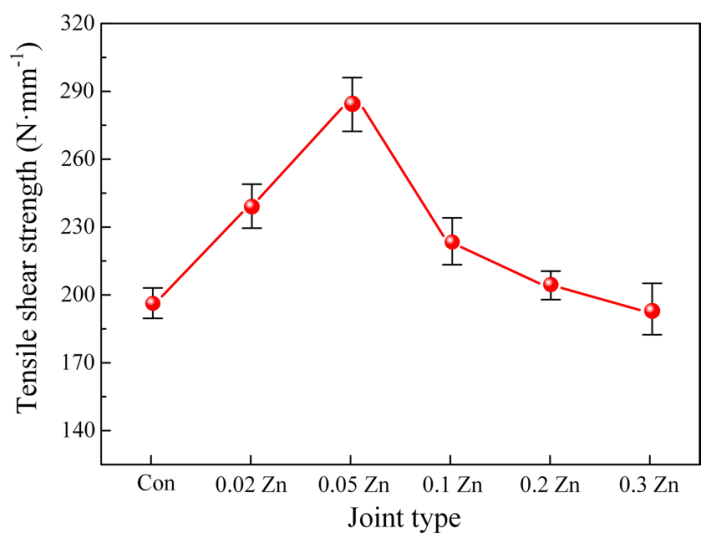

Fig. 10 Tensile shear strength of joints under different welding processes are related to the differences of the joint formation and the microstructure.

The fracture positions of the joints under different welding processes are displayed in Fig. 11. It is noteworthy that the SZs at all joints are completely separated from the lower plate during the tensile shear test. These results show that the main propagation paths of the fracture cracks are along the boundaries between the SZ bottom and the TMAZ in the lower plate (Fig. 2b). The similar fracture characteristic has also been reported by Niu et al. [16]. The boundary between the SZ bottom and the TMAZ in lower plate is the weak area for the FSLW joint of $\mathrm{Al} / \mathrm{Mg}$ dissimilar alloys. Therefore, the ELW and the boundary between the SZ bottom and the TMAZ in the lower plate (Fig. 3) play important roles which directly affect the tensile property of the FSLW joint. Besides, the IMCs are another significant factor determining the joint quality [30].

For the conventional joint, the ELW is small due to the large cold lap (Fig. 2a). The RS bears the main load during tensile shear test in this study (Fig. 1). The crack easily initiates along the cold lap at the RS. Therefore, the other fracture path, which initiates from the cold lap and then extends into the SZ, exists in the conventional joint, as shown in Fig. 11a. The boundary length between the SZ bottom and the TMAZ in the lower plate at the conventional joint is the smallest because of the poor material flow behavior (Fig. 2a). Figure 12a presents the fracture surface morphologies of the conventional joint. The XRD results on these fracture surfaces reveal that the IMCs on the surfaces are mainly $\mathrm{Al}_{12} \mathrm{Mg}_{17}$ and $\mathrm{Al}_{3} \mathrm{Mg}_{2}$ (Fig. 13a). The large and continuously distributed $\mathrm{Al}-\mathrm{Mg}$ IMCs exist at the boundary between the SZ bottom and the TMAZ in the lower plate, conforming the above results of the microstructures shown in Fig. 4. Gan and Jin [15] reported that the micro-hardness of the Al-Mg IMCs is obviously larger than that of the $\mathrm{Mg}-\mathrm{Zn}$ IMCs. The hard and brittle $\mathrm{Al}-\mathrm{Mg}$ IMCs are more easily to become the crack source compared to the $\mathrm{Mg}-\mathrm{Zn}$ IMCs, and cracks propagate faster along the $\mathrm{Al}-\mathrm{Mg}$ IMCs. Therefore, the tensile shear strength of the conventional joint is the smallest (Fig. 10).

For the $\mathrm{Zn}$-added joints with different interlayer thicknesses of $0.02,0.05,0.1$ and $0.2 \mathrm{~mm}$, the size of the cold lap is reduced and the area of the SZ bottom is increased due to the lubrication of the molten $\mathrm{Zn}$, increasing the ELW and the boundary length between the SZ bottom and the TMAZ in the lower plate. Figure $12 \mathrm{~b}$ and $\mathrm{c}$ presents the fracture surface morphologies of the $\mathrm{Zn}$-added joints. The fine $\mathrm{Mg}-\mathrm{Zn}$ and $\mathrm{Al}-\mathrm{Mg}-\mathrm{Zn}$ IMCs (Fig. 13b) are discontinuously distributed along with the boundaries. The cracks are not easily formed in the $\mathrm{Mg}-\mathrm{Zn}$ and $\mathrm{Al}-\mathrm{Mg}-\mathrm{Zn}$ IMCs compared to that in the Al-Mg IMCs, and the morphologies of the $\mathrm{Mg}-\mathrm{Zn}$ and $\mathrm{Al}-\mathrm{Mg}-\mathrm{Zn}$ IMCs can retard the propagation of cracks to a certain extent. These are the reasons why 

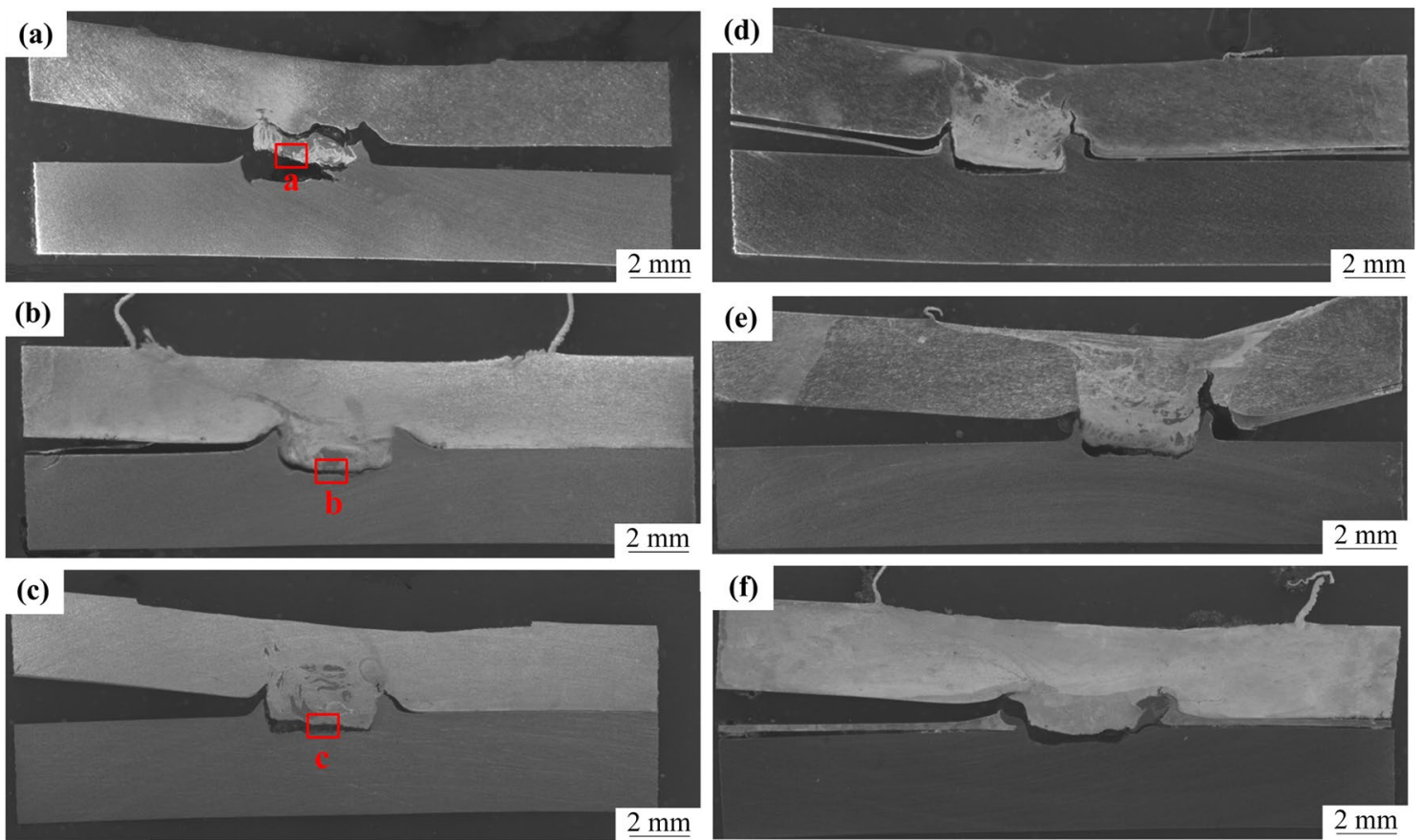

Fig. 11 Fracture locations: a the conventional joint, b $0.02 \mathrm{~mm}, \mathbf{c} 0.05 \mathrm{~mm}, \mathbf{d} 0.1 \mathrm{~mm}$, e $0.2 \mathrm{~mm}, \mathbf{f} 0.3 \mathrm{~mm} \mathrm{Zn}$-added joints
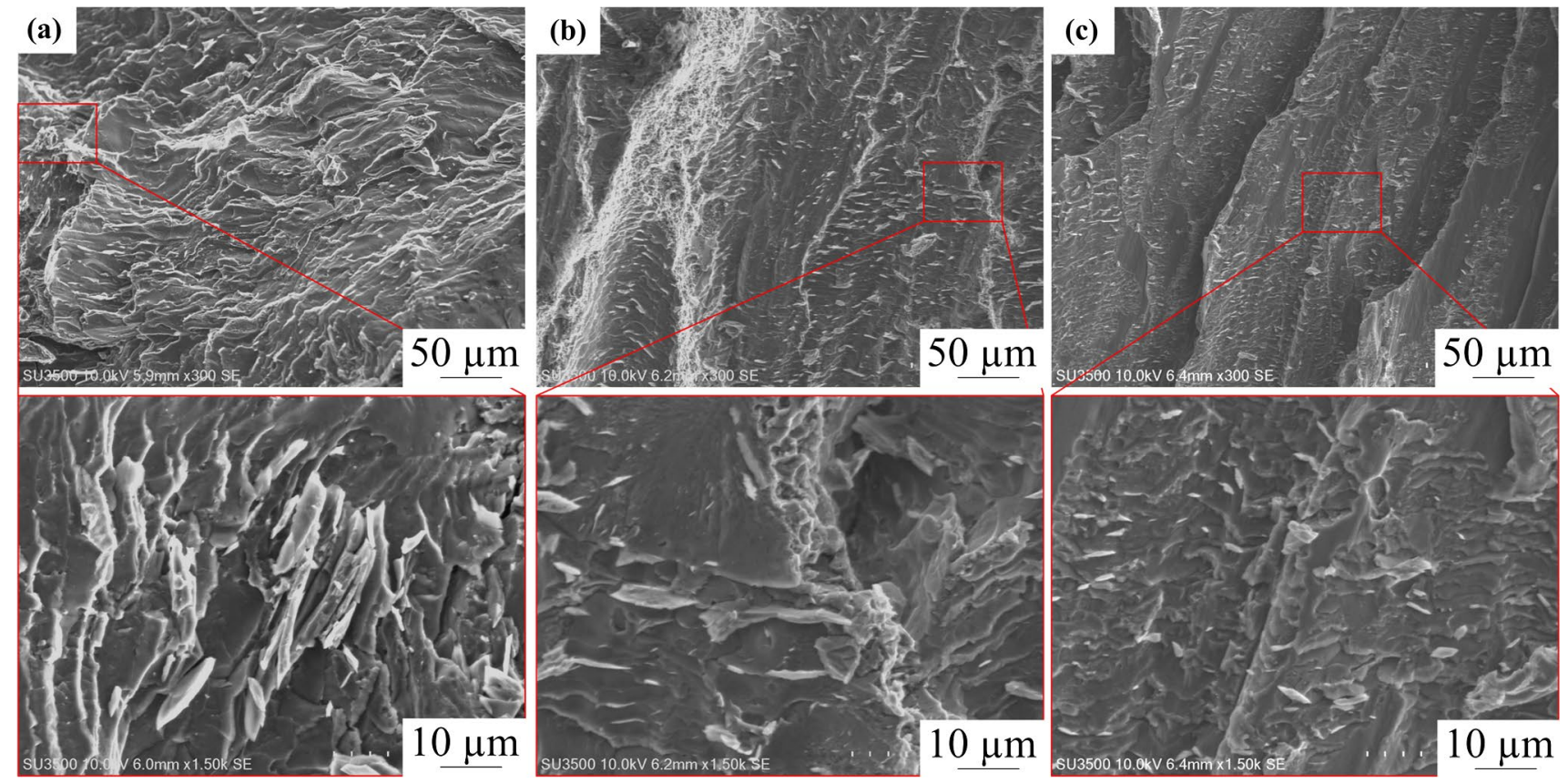

Fig. 12 Fracture surface morphologies of the regions marked in Fig. 11: a region a, b region b, c region c

the tensile property of the joint is improved by the $\mathrm{Zn}$ foil addition.

The differences in the ELW values are small for the $\mathrm{Zn}$ added joints (Fig. 3), so the increase in the joint strength is mainly related to the differences of the boundary length and the IMCs. The size of the Mg-Zn IMCs and superfluous Zn is large in the $0.3 \mathrm{~mm} \mathrm{Zn-added} \mathrm{joint,} \mathrm{and} \mathrm{the} \mathrm{cavity} \mathrm{defect}$ exists in the SZ bottom, resulting in the decrease in tensile shear strength although the ELW and the boundary length are both increased compared to the conventional joint. For the $0.2 \mathrm{~mm} \mathrm{Zn}$-added joint, the continuously distributed IMCs and the superfluous $\mathrm{Zn}$ in the SZ have no obvious 

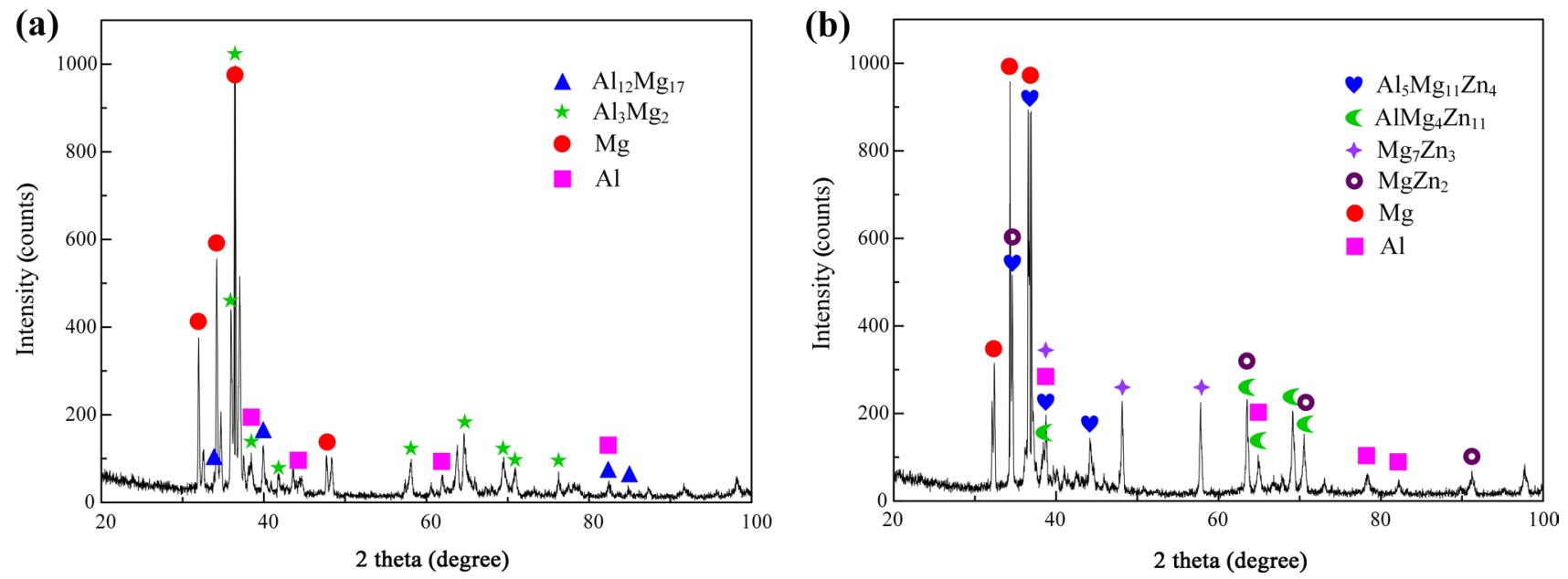

Fig. 13 XRD patterns on the fracture surfaces: $\mathbf{a}$ the conventional joint, $\mathbf{b}$ the $0.05 \mathrm{~mm} \mathrm{Zn-added} \mathrm{joint}$

advantage for improving the tensile property. The discontinuously distributed $\mathrm{Mg}-\mathrm{Zn}$ IMCs replacing the $\mathrm{Al}-\mathrm{Mg}$ IMCs are dispersed in the $\mathrm{SZ}$ at the $0.1 \mathrm{~mm}$ joint, greatly increasing the tensile shear strength combined with the enlarged boundary length. For the $0.02 \mathrm{~mm}$ joint, although some Al-Mg IMCs are formed in the SZ, the IMCs at the boundary between the SZ bottom and the TMAZ in the lower plate are almost the quite fine $\mathrm{Al}-\mathrm{Mg}-\mathrm{Zn}$. Its tensile shear strength is higher than that of the 0.1 or $0.2 \mathrm{~mm}$ joint. For the $0.05 \mathrm{~mm}$ joint, the ELW and the boundary length are larger than those of the $0.02 \mathrm{~mm}$ joint (Figs. 2, 3). The very fine $\mathrm{Mg}-\mathrm{Zn}$ and $\mathrm{Al}-\mathrm{Mg}-\mathrm{Zn}$ IMCs completely replace the $\mathrm{Al}-\mathrm{Mg}$ IMCs, and discontinuously distribute at the boundary between the SZ bottom and the TMAZ in the lower plate (Fig. 12c). Therefore, the maximum tensile shear strength of $276 \mathrm{~N} \mathrm{~mm}^{-1}$ is obtained when the $0.05 \mathrm{~mm} \mathrm{Zn}$ foil is used in this study.

\section{Conclusions}

1. The smallest ELW and boundary length between the SZ and the TMAZ in the lower plate were formed under the conventional FSLW. The continuously distributed AlMg IMCs were concentrated at the boundary between the SZ and TMAZ leading to the poor tensile property of the conventional joint.

2. Due to the addition of the $\mathrm{Zn}$ foils with $0.02,0.05$ and $0.1 \mathrm{~mm}$ thicknesses, the lubrication of the molten $\mathrm{Zn}$ improved the flowability of materials in the SZ, enlarging the ELW and the boundary length between the SZ and the TMAZ in the lower plate. Meanwhile, the discontinuously distributed $\mathrm{Mg}-\mathrm{Zn}$ and $\mathrm{Al}-\mathrm{Mg}-\mathrm{Zn}$ IMCs particles were formed in the SZ replacing the continuously distributed Al-Mg IMCs. These morphologies were beneficial to improving the tensile strength of the $\mathrm{Al} / \mathrm{Mg}$ lap joint.

3. The joints showed different morphologies and properties by the addition of the $\mathrm{Zn}$ foils with different thicknesses. The ELW was increased with increasing the $\mathrm{Zn}$ foil thickness. Some $\mathrm{Al}-\mathrm{Mg}$ IMCs still existed in the $\mathrm{SZ}$ when the $\mathrm{Zn}$ content was insufficient. The $\mathrm{Mg}-\mathrm{Zn}$ IMCs presented a continuous distribution, and the cavity defect was easily formed when the $\mathrm{Zn}$ content in the $\mathrm{SZ}$ was excess. These results were not conducive to the improvement of the tensile property.

4. The thickness of the $\mathrm{Zn}$ interlayer was a significant parameter for the FSLW joint of $\mathrm{Al} / \mathrm{Mg}$ dissimilar alloys. The $\mathrm{Zn}$ foil with $0.05 \mathrm{~mm}$ thickness was the optimal choice in this study, and the maximum tensile shear strength of $276 \mathrm{~N} \mathrm{~mm}^{-1}$ was obtained.

Acknowledgement This work is supported by the National Natural Science Foundation of China (No. 51874201).

\section{References}

[1] D. Mishra, R.B. Roy, S. Dutta, S.K. Pal, D. Chakravarty, J. Manuf. Process. 36, 373 (2018)

[2] F.B. Argesi, A. Shamsipur, S.E. Mirsalehi, Acta Metall. Sin. (Engl. Lett.) 31(11), 1183 (2018)

[3] R. Borrisutthekul, Y. Miyashita, Y. Mutoh, Sci. Technol. Adv. Mater. 6, 199 (2005)

[4] H.T. Zhang, J.Q. Song, Mater. Lett. 65, 3292 (2011)

[5] L.H. Shah, N.H. Othman, A. Gerlich, Sci. Technol. Weld. Join. 23, 256 (2018)

[6] H.J. Liu, H. Fujii, M. Maeda, K. Nogi, J. Mater. Process. Technol. 142, 692 (2003)

[7] W.S. Chang, S.R. Rajesh, C.K. Chun, H.J. Kim, J. Mater. Sci. Technol. 27, 199 (2011) 
[8] Y.F. Wang, J. An, K. Yin, M.S. Wang, Y.S. Li, C.X. Huang, Acta Metall. Sin. (Engl. Lett.) 31(8), 878 (2018)

[9] W.F. Xu, Y.X. Luo, M.W. Fu, Mater. Charact. 138, 48 (2018)

[10] Y. Huang, X. Meng, Y. Xie, L. Wan, Z. Lv, J. Cao, J. Feng, Compos. Part A Appl. Sci. Manuf. 105, 235 (2018)

[11] Z.J. Yan, X.S. Liu, H.Y. Fang, Acta Metall. Sin. (Engl. Lett.) 29(12), 1161 (2016)

[12] B. Fu, G. Qin, F. Li, X. Meng, J. Zhang, C. Wu, J. Mater. Process. Technol. 218, 38 (2015)

[13] S. Ji, Z. Li, L. Zhang, Z. Zhou, P. Chai, Mater. Des. 103, 160 (2016)

[14] J. Mohammadi, Y. Behnamian, A. Mostafaei, H. Izadi, T. Saeid, A.H. Kokabi, A.P. Gerlich, Mater. Charact. 101, 189 (2015)

[15] R. Gan, Y. Jin, Sci. Technol. Weld. Join. 23, 164 (2018)

[16] S. Niu, S. Ji, D. Yan, X. Meng, X. Xiong, J. Mater. Process. Technol. 263, 82 (2019)

[17] S. Ji, S. Niu, J. Liu, X. Meng, J. Mater. Process. Technol. 267, 141 (2019)

[18] M. Farahani, M. Divandari, Int. J. Syst. Signal Control Eng. Appl. 9, 86 (2016)

[19] S. Ji, Z. Li, Z. Zhou, B. Wu, J. Mater. Eng. Perform. 26, 5085 (2017)
[20] P.L. Li, Z.F. Xu, C. Yu, H. Lu, J.S. Yao, G.Y. Chen, Acta Metall. Sin. (Engl. Lett.) 25(3), 225 (2012)

[21] Y. Yue, Z. Li, S. Ji, Y. Huang, Z. Zhou, J. Mater. Sci. Technol. 32, $671(2016)$

[22] X. Dai, H. Zhang, H. Zhang, J. Liu, J. Feng, Mater. Sci. Technol. 32, 164 (2016)

[23] B. Chen, Y. Wang, C. Xiao, M. Zhang, G. Ni, D. Li, Mater. Sci. Technol. 34, 703 (2018)

[24] B.A. Saad, W.D. Mohammad, J.H. Daniel, A.W. Muhammad, M.O. Ayman, T.W. Liao, Acta Metall. Sin. (Engl. Lett.) 29(9), 869 (2016)

[25] S. Firouzdor, V. Kou, Weld. J. 88, 213 (2009)

[26] A. Abdollahzadeh, A. Shokuhfar, J.M. Cabrera, A.P. Zhilyaev, H. Omidvar, J. Manuf. Process. 34, 18 (2018)

[27] F. Liu, Z. Zhang, L. Liu, Mater. Charact. 69, 84 (2012)

[28] Y. Zhang, Z. Luo, Y. Li, Z.M. Liu, Z.Y. Huang, Mater. Des. 75, 166 (2015)

[29] H.J. Liu, Y.Y. Hu, Y.X. Peng, C. Dou, Z.G. Wang, J. Mater. Process. Technol. 238, 244 (2016)

[30] S.T. Jose, Water Energy Int. 69, 24 (2012) 